\title{
Plasma $\alpha$-Ketoglutarate in Urea Cycle Enzymopathies and Its Role as a Harbinger of Hyperammonemic Coma
}

\author{
MARK L. BATSHAW, ${ }^{(20)}$ MACKENZIE WALSER, SAUL W. BRUSILOW \\ Departments of Pediatrics, Medicine, Pharmacology, and Experimental Therapeutics, and the John F. Kennedy \\ Institute, Johns Hopkins Medical Institutions, Baltimore, Maryland, USA
}

\section{Summary}

Metabolic observations during early stages of hyperammonemia in two infants with ornithine transcarbamylase deficiency suggest that plasma $\alpha$-ketoglutarate concentration $(|\alpha-K G|)$ becomes subnormal before the development of hyperammonemic coma. In one case, plasma $\left[\mathrm{NH}_{4}{ }^{+}\right]$remained normal until $\mathbf{4 0}$ days of age when it rose to $57 \mu \mathrm{M}$. However, this hyperammonemia was preceded by a fall in plasma $[\alpha-K G \mid$ to $15 \mu \mathrm{M}$ at 27 days of age. It was only after severe hyperammonemia was established at $\mathbf{5 0}$ days of age that coma supervened. In the second case, plasma $[\alpha-K G \mid$ became subnormal $(14 \mu \mathrm{M}) 8$ days before the rise in plasma ammonium concentration $\left[\mathrm{NH}_{4}^{+}\right](52 \mu \mathrm{M})$ and 14 days before the onset of hyperammonemic coma. In eight patients with urea cycle enzymopathies, there was a highly significant $(P<0.01)$ negative linear correlation between $\left[\mathrm{NH}_{4}{ }^{+} \mid\right.$and $[\alpha-K G]$. In patients with portalsystemic encephalopathy, there was a similar relationship between $\left[\mathrm{NH}_{4}{ }^{+}\right]$and $[\alpha-K G]$, although the absolute $[\alpha-K G]$ levels in these patients were normal $(23 \pm 4 \mu \mathrm{M})$ while the patients were hyperammonemic $(88 \pm 25 \mu \mathrm{M})$.

\section{Speculation}

The inverse linear correlation between $\left[\alpha-K G \mid\right.$ and $\left[\mathrm{NH}_{4}{ }^{+}\right]$ levels in patients with urea cycle enzymopathies suggest that plasma $[\alpha-K G]$ may presage hyperammonemic coma. However, the different $[\alpha-K G]$ levels in patients with cirrhosis and portalsystemic shunting imply different pathophysiologic mechanisms for hyperammonemic coma as compared to hepatic coma.

Studies from this laboratory have suggested that supplementation of a low-protein diet with a mixture of essential amino acids and their nitrogen-free analogues can sustain normal growth in children with congenital defects of the urea cycle (6). However, in most of these cases, a hyperammonemic crisis occurred during the first 2 years of life and proved fatal $(13,15,17)$.

We have reported that plasma $\alpha$-ketoglutarate concentration $([\alpha-K G])$ is inversely correlated with plasma ammonium concentration, $\left[\mathrm{NH}_{4}{ }^{+}\right]$, in low-birth-weight infants (2). Previous studies of $[\alpha-K G]$ in liver disease, however, suggest these levels may be increased $(8,12)$. We now report studies of this relationship in patients with congenital urea cycle defects and portal-systemic encephalopathy. We also present metabolic observations from the early stages of hyperammonemic coma in two male infants with ornithine transcarbamylase (OTC) deficiency. These observations suggest that plasma $[\alpha-K G]$ becomes subnormal before the development of hyperammonemic coma and may be a harbinger of coma in patients with urea cycle defects.

SUBJECTS

\section{UREA CYCLE ENZYMOPATHIES}

Two unrelated males with OTC deficiency were studied during the development of hyperammonemic coma. Patient C. S. was a full-term infant who was rescued from hyperammonemic coma at 4 days of age by the use of peritoneal dialysis. He was placed on a protein-restricted diet supplemented with essential amino acids and their nitrogen-free analogs as previously described (17). At 2 wk of age, he received $120 \mathrm{kcal} / \mathrm{kg} /$ day and $2 \mathrm{~g}$ protein $/ \mathrm{kg} /$ day. He gained an average of $20 \mathrm{~g} /$ day during the succeeding month. Developmental and neurologic examination and electroencephalogram at five wk of age were within normal limits.

The infant's clinical condition remained stable until 49 days of age when he developed vomiting and lethargy. Plasma $\left[\mathrm{NH}_{4}{ }^{+}\right]$ increased to $150 \mu \mathrm{M}$, and urinary orotic acid increased to 5017 $\mu \mathrm{g} / \mathrm{mg}$ creatinine. He became comatose on day 51 after which peritoneal dialysis was begun. The electroencephalogram became isoelectric at 55 days of age, and life support systems were discontinued. Liver obtained by percutaneous biopsy had $3.6 \%$ of normal activity of OTC and normal activities of the other four urea cycle enzymes. ${ }^{1}$ This paper describes the metabolic events during his final 5 wk of life.

The second male, R. D., was also rescued from hyperammonemic coma by peritoneal dialysis. He was placed on a similar dietary regimen as patient $C$. S. However, he experienced intermittent hyperammonemic episodes throughout his life, was profoundly mentally retarded, and required tube feedings. His height and weight were within normal limits. However, his head circumference was below the third percentile. This study describes the metabolic events during a reversible hyperammonemic episode at 13 months of age. As with previous episodes, the child had recurrent vomiting and became stuperous over a 2-day period. On this occasion, he responded to conservative management including administration of $2 \mathrm{~g}$ sodium benzoate (7). He did not survive a similar episode at 15 months of age. Liver obtained at time of death had $0.05 \%$ of normal activity of OTC and normal activities of the other four urea cycle enzymes. ${ }^{1}$

In addition to these patients, six other children with urea cycle enzymopathies were studied. They included two patients with partial OTC deficiency, one with partial carbamyl phosphate synthetase deficiency, two with argininosuccinic acid synthetase deficiency, and one with argininosuccinase deficiency. They were all asymptomatic while variously treated with protein restriction, nitrogen-free analogues of essential amino acids and dietary arginine supplementation (Table 1).

\section{PORTAL SYSTEMIC ENCEPHALOPATHY (PSE)}

Five adults with PSE were also studied. All had biopsy-proven chronic liver disease (either alcoholic cirrhosis or post-necrotic cirrhosis) with varying degrees of hepatocellular dysfunction. All had some degree of hyperammonemia during the study (Table 2).

\section{METHODS}

Fasting blood samples were obtained in the morning. Plasma $\left[\mathrm{NH}_{4}{ }^{+}\right]$was measured on $0.05 \mathrm{ml}$ plasma within $30 \mathrm{~min}$ of

\footnotetext{
${ }^{1}$ Activities of urea cycle enzymes in liver were measured by Dr. P. Snodgrass,
} Veterans Administration Hospital, Indianapolis, IN. 
Table 1. Relationship of plasma ammonium and $[\alpha-K G]$ in asymptomatic patients with urea cycle enzymopathies

\begin{tabular}{|c|c|c|c|c|c|c|c|c|c|c|}
\hline Patient & Sex & Age & $\begin{array}{c}\text { Enzyme } \\
\text { defect }\end{array}$ & Therapy & $\begin{array}{c}\text { No. of } \\
\text { observa- } \\
\text { tions }\end{array}$ & {$\left[\mathrm{NH}_{4}{ }^{+}\right]$} & {$[\alpha-\mathbf{K G}]$} & $r$ & $\mathrm{y}$ & $P<$ \\
\hline L. A. & $\mathbf{F}$ & $17 \mathrm{yr}$ & CPS $^{\prime}$ & $\mathrm{KA}+\mathrm{PR}$ & 21 & $36 \pm 13^{2}$ & $14.2 \pm 4.6$ & -0.81 & $-0.28 x+25$ & 0.001 \\
\hline C. $\mathbf{S}$. & $\mathbf{M}$ & 2 mos. & OTC & $\mathbf{K A}+\mathbf{P R}$ & 21 & $42 \pm 17$ & $11.0 \pm 7.0$ & -0.79 & $-0.33 x+25$ & 0.001 \\
\hline R. D. & $\mathbf{M}$ & 13 mos. & OTC & $\mathbf{K A}+\mathbf{P R}$ & 20 & $49 \pm 22$ & $9.9 \pm 6.5$ & -0.73 & $-0.22 x+21$ & 0.001 \\
\hline S. B. & $\mathbf{F}$ & $7 \mathrm{yr}$ & OTC & PR & 11 & $55 \pm 33$ & $13.6 \pm 5.0$ & -0.75 & $-0.12 x+20$ & 0.01 \\
\hline C. L. & $\mathbf{F}$ & $22 \mathrm{yr}$ & OTC & PR & 51 & $50 \pm 22$ & $11.9 \pm 5.8$ & -0.71 & $-0.18 \times+21$ & 0.001 \\
\hline A. $S$. & $\mathbf{F}$ & 3 mos. & AS & $\mathbf{K A}+\mathbf{A R G}+\mathbf{P R}$ & 6 & $32 \pm 17$ & $16.8 \pm 6.3$ & -0.94 & $-0.35 x+28$ & 0.01 \\
\hline W. S. & $\mathbf{M}$ & $2 \mathrm{yr}$ & AS & ARG & 14 & $43 \pm 16$ & $13.3 \pm 5.4$ & -0.86 & $-0.30 x+26$ & 0.001 \\
\hline N. M. & $\mathrm{F}$ & 3 mos. & AL & ARG & 39 & $36 \pm 25$ & $17.5 \pm 4.8$ & -0.65 & $-0.12 x+22$ & 0.001 \\
\hline
\end{tabular}

${ }^{1}$ CPS, carbamyl phosphate synthetase; KA, nitrogen-free analogues of amino acids; PR, protein restriction approximately $1 \mathrm{~g} / \mathrm{kg} / \mathrm{day}$; AS, acid synthetase argininosuccinic; ARG, arginine supplement 2 to $4 \mathrm{mmoles} / \mathrm{kg} / \mathrm{day} ; \mathrm{AL}$, argininosuccinase.

${ }^{2} \mu \mathrm{M} \pm$ S.D.

Table 2. Relationship of plasma ammonium and $[\alpha-K G]$ in patients with portal systemic encepatholopathy

\begin{tabular}{|c|c|c|c|c|c|c|}
\hline Patient & Sex & Age & $\begin{array}{l}\text { No. of } \\
\text { observa- } \\
\text { tions }\end{array}$ & {$\left[\mathrm{NH}_{4}{ }^{+}\right]$} & {$[\alpha-\mathrm{KG}]$} & $r$ \\
\hline J. J. & $\mathbf{M}$ & 35 & 34 & $85 \pm 13^{1}$ & $22.7 \pm 3.0$ & -0.39 \\
\hline G. J. & F & 48 & 16 & $71 \pm 21$ & $21.5 \pm 4.8$ & -0.18 \\
\hline D. $\mathbf{w}$. & $\mathrm{F}$ & 49 & 4 & $80 \pm 25$ & $20.5 \pm 7.1$ & -0.92 \\
\hline H. H. & $\mathbf{M}$ & 60 & 16 & $93 \pm 20$ & $22.2 \pm 3.5$ & -0.17 \\
\hline R. C. & $\mathbf{M}$ & 53 & 3 & $149 \pm 6$ & $15.6 \pm 3.0$ & +0.60 \\
\hline
\end{tabular}

${ }^{\prime} \mu \mathrm{M} \pm$ S.D.

collection, using a cation exchange resin method as described previously (3). Glutamine, glutamate, alanine, and $[\alpha-K G]$ were determined by micromodifications of enzymatic fluorometric techniques (4). Normal ranges were determined from observations in eight normal infants $\left(\mu \mathrm{M} \pm 2 \mathrm{~S}\right.$. D.): $\left[\mathrm{NH}_{4}{ }^{+}\right], 10$ to 42; glutamine, 417 to 801 ; glutamate, 55 to 101 ; alanine, 180 to 496 ; [ $\alpha-\mathrm{KG}$ ], 15.7 to $25.6(2)$. These values are similar to those reported by other $(1$, 14).

\section{RESULTS}

\section{RELATIONSHIP BETWEEN $\left[\mathrm{NH}_{4}^{+}\right]$AND $[\alpha-\mathrm{KG}]$}

Table 1 shows the relationship between $\left[\mathrm{NH}_{4}^{+}\right]$and $[\alpha-\mathrm{KG}]$ in the eight patients with urea cycle enzymopathies. In each case, there was a highly significant, $(P<0.01)$ negative linear correlation between $\left[\mathrm{NH}_{4}^{+}\right]$and $[\alpha-\mathrm{KG}]$. The intercepts were similar but there was some variation in the slopes.

Table 2 shows the relationship between $\left[\mathrm{NH}_{4}^{+}\right]$and $[\alpha-\mathrm{KG}]$ in five patients with PSE. Four of the five patients studied had negative inverse linear correlations between $\left[\mathrm{NH}_{4}{ }^{+}\right]$and $[\alpha-\mathrm{KG}]$ ranging from -0.17 to -0.92 . Using Fisher's test of combination of probabilities (9), this relationship was significant at the 0.025 level for the group as a whole. This indicates that in patients with PSE, $\left[\mathrm{NH}_{4}{ }^{+}\right]$, and $[\alpha-\mathrm{KG}]$ levels are negatively correlated. However, mean $[\alpha-\mathrm{KG}]$ in patients with PSE $(23.0 \pm 4.0 \mu \mathrm{M})$ was normal and, furthermore, was higher than in patients with urea cycle defects $(14.0 \pm 6.0 \mu \mathrm{M})$ despite a higher mean $\left[\mathrm{NH}_{4}{ }^{+}\right](88$ $\pm 25 \mu \mathrm{M}$ ) in the PSE patients.

\section{$\alpha$-KETOGLUTARATE AS A HARBINGER OF HYPERAMMONEMIC COMA}

Figure 1 shows the course of the plasma $\left[\mathrm{NH}_{4}^{+}\right],[\alpha-\mathrm{KG}]$, glutamate, glutamine, and alanine in patient C. S. Between 18 and 27 days of age, these substrates were all within normal limits. Plasma $\left[\mathrm{NH}_{4}^{+}\right.$] remained normal or near normal until $\mathbf{4 0}$ days of age when it rose to $57 \mu \mathrm{M}$. However, this hyperammonemia was preceded by a fall in the plasma $[\alpha-K G]$ at 27 days of age $(15 \mu \mathrm{M})$ to be followed in sequence by increased levels of glutamine ( 998 $\mu \mathrm{M})$ and glutamate $(146 \mu \mathrm{M})$ at 36 and 40 days of age, respectively.
It was only after severe hyperammonemia was established at $\mathbf{5 0}$ days of age that coma supervened.

Figure 2 shows the pattern of metabolic abnormalities in patient R. D. during a reversible episode of hyperammonemic coma at 13 months of age. The sequence of biochemical abnormalities preceding hyperammonemic coma was similar to that noted in C. S. Plasma $[\alpha-K G]$ became subnormal on day $1(14 \mu \mathrm{M})$ followed by increasing levels of glutamate $(102 \mu \mathrm{M})$ and glutamine $(840 \mu \mathrm{M})$ on days 7 and 8 . Plasma $\left[\mathrm{NH}_{4}^{+}\right]$became abnormal $(52 \mu \mathrm{M})$ on day 9 . The child became stuporous on day 14. Thus, in both $C$. $S$. and R. D., plasma $\alpha-K G$ became abnormally low 1 to 2 wk before clinically significant hyperammonemia was evident.

\section{DISCUSSION}

The finding of a sequence of metabolic events leading to hyperammonemic coma suggests that $[\alpha-K G]$ may be a harbinger of nitrogen accumulation in urea cycle enzymopathies. In an attempt to explain this sequence, it is instructive to review the known relationships between $\left[\mathrm{NH}_{4}{ }^{+}\right]$and $[\alpha-\mathrm{KG}]$ in tissues, even though plasma concentration may not necessarily reflect intramitochondrial or cytosolic events. The first indication of nitrogen accumulation is the intramitochondrial consumption of $[\alpha-K G]$ favoring glutamate synthesis. This is presumably due to a shift of the glutamate dehydrogenase reaction secondary to $\mathrm{NH}_{4}^{+}$accumulation. As glutamate accumulates, the glutamine synthetase reaction would favor glutamine synthesis and accumulation. Subsequent $\mathrm{NH}_{4}^{+}$formation would lead to a rise in plasma alanine by the glutamate-pyruvate transaminase reaction. When this labile nitrogen pool is saturated, further nitrogen accumulation would lead to hyperammonemia.

The inverse correlation between $[\alpha-\mathrm{KG}]$ and $\left[\mathrm{NH}_{4}{ }^{+}\right]$in patients with urea cycle enzymopathies and portal systemic encephalopathy may represent changes in the redox state of mitochondria in the direction of oxidation. Bessman and Bessman (5) suggested that depletion of $[\alpha-K G]$ via the glutamate dehydrogenase reaction might impair energy production in hyperammonemic states. By measuring cytoplasmic and mitochondrial redox states, several studies have shown that ammonium alters the intramitochondrial redox state of brain $(10,11)$ or liver $(16)$ in the direction of 

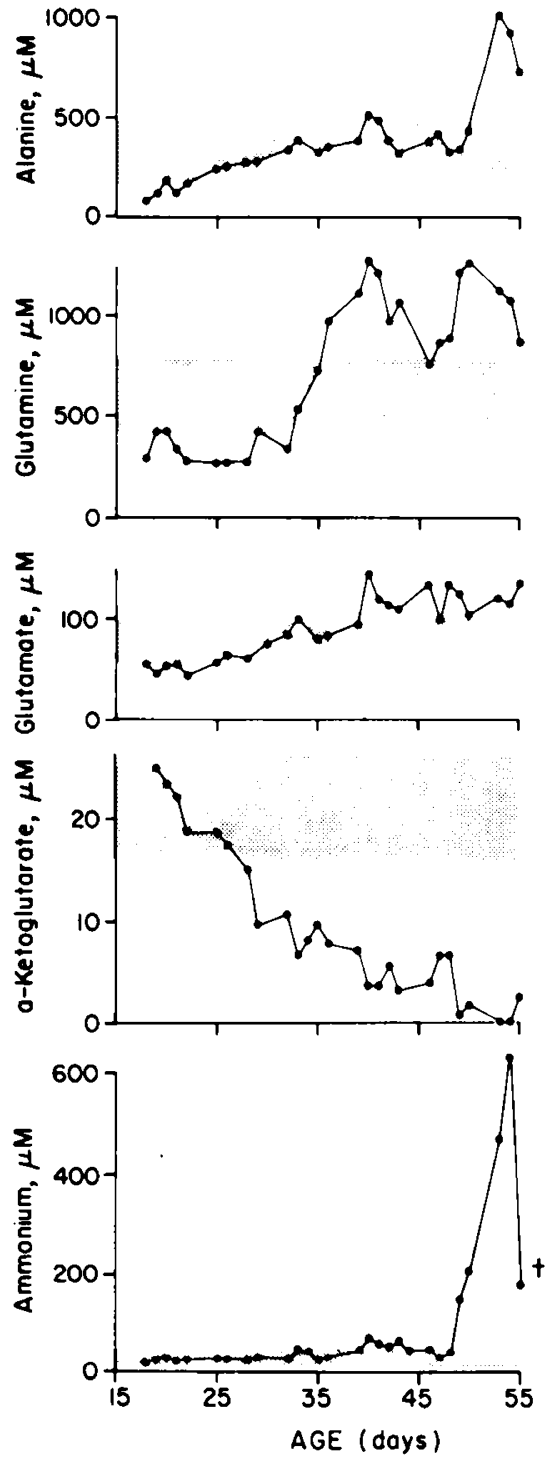

Fig. 1. The course of plasma levels of ammonium, $[\alpha-K G]$, glutamate, glutamine, and alanine in patient C. S. during terminal hyperammonemia.

oxidation. Thus, it is not surprising to observe similar changes (as manifested by a decrease in the circulating concentration of [ $\alpha$ $\mathbf{K G}$ ] in hyperammonemic patients.

The present data suggest that $[\alpha-K G]$ may be a harbinger of hyperammonemic coma in inborn errors of urea synthesis. Thus, the measurement of plasma $[\alpha-K G]$ may be a useful adjunct to the measurement of $\left[\mathrm{NH}_{4}^{+}\right]$in the management of these patients. Furthermore, the finding of different $[\alpha-K G]$ levels in patients with hyperammonemia secondary to urea cycle enzymopathies as compared to patients with portal systemic encephalopathy implies different pathophysiologic mechanisms of coma in these two disorders.

\section{REFERENCES AND NOTES}

1. Allyne, G. A., and Scullard, G. H.: Blood keto acids in malnutrition. Am. J. Clin. Nutr., 22: 1139 (1969).

2. Batshaw, M. L., and Brusilow, S.: Asymptomatic hyperammonemia in low birthweight infants. Pediatr. Res., 12: 221 (1978).

3. Batshaw, M. L., Brusilow S., and Walser M.: Treatment of carbamyl phosphate synthetase deficiency with keto-analogues of essential amino acids. N. Engl. J. Med., 292: 1085 (1975).

4. Bergmeyer, H. U.: Methods of Enzymic Analysis. (Academic Press, lnc., New York, 1974)

5. Bessman, S. P., and Bessman, A. N.: The cerebral and peripheral uptake of ammonia in liver disease with a hypothesis for the mechanism of hepatic coma. J. Clin. Invest., 34: 622 (1955).
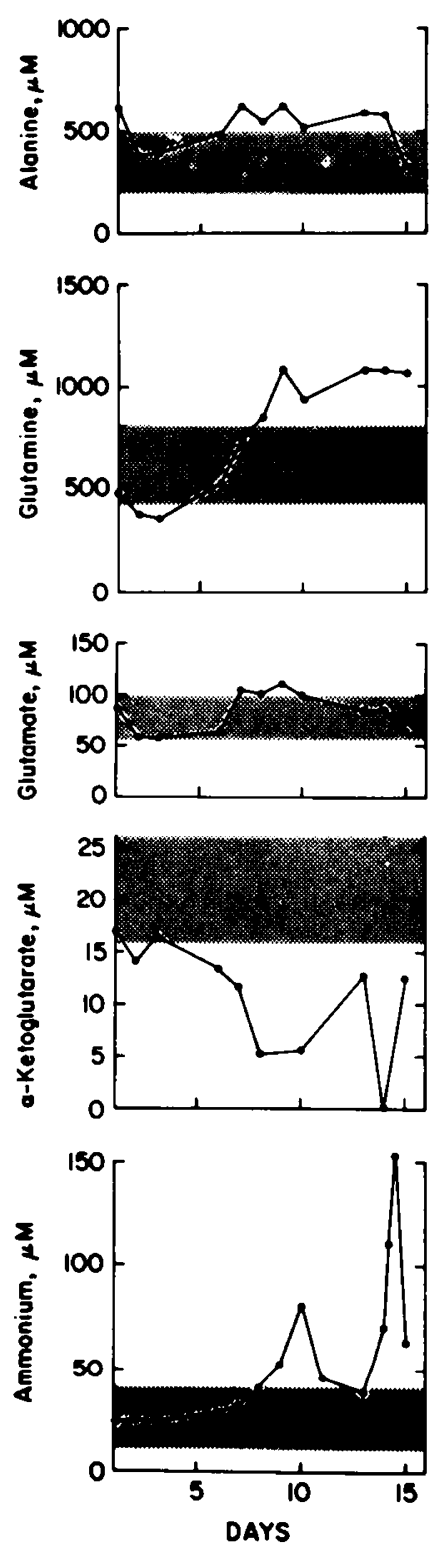

Fig. 2. The course of plasma levels of ammonium, $[\alpha-K G]$, glutamate, glutamine, and alanine in patient R. D. during an episode of byperammonemic coma.

6. Brusilow, S., Batshaw, M. L., and Walser, M.: Use of ketoacids in inborn errors of urea synthesis In: M. Winick: Nutritional Management of Genetic Disorders. pp. 65-78 (John Wiley \& Sons, New York, 1979).

7. Brusilow, S., Tinker, J., and Batshaw M. L.: Amino acid acylation: a mechanism of nitrogen excretion inborn errors of urea synthesis. Science (Wash. D. C.), 207: 659 (1980).

8. Dawson, A. R., deGroote, J., Rosenthal, W. S., and Sherlock, S.: Blood pyruvic acid and $\alpha$-ketoglutaric acid levels in liver disease and hepatic coma. Lancet, l: 392 (1957).

9. Fisher, R. A.: Statistical methods for research workers. Tenth edition. pp. 99-101 (Oliver and Boyd, Edinburgh, 1946).

10. Hawkins, R. A., Miller, A. L., Nielsen, R. C., and Veech, R. L.: The acute action of ammonia on rat brain metabolism in vivo. Biochem. J., 134: 1001 (1973).

11. Hindfelt, B., Plum, F., and Duffy, T. E.: Effect of acute ammonia intoxication on cerebral metabolism in rats with porta-caval shunts. J. Clin. Invest., 59: 386 (1977).

12. Laudahn, G.: Fermentaktivitater und Konzentration von stoffwechselzwischen produkten im blut bei leber-und herzkrankheiten. Klin. Wochenschr., 16: 850 (1959).

13. McReynolds, J. W., Mantagos, S., Brusilow, S., and Rosenberg, L. E.: Treatment of complete ornithine transcarbamylase deficiency with nitrogen-free analogues of essential amino acids. J. Pediatr., 93: 421 (1978).

14. Pohlandt, F.: Plasma amino acid concentrations in newborn infants breast-fed ad libitum. J. Pediatr., 92: 614 (1978).

15. Thoene, J., Batshaw, M. L., Spector, E., Kulovich, S., Brusilow, S., Walser, M and Nyhan, W.: Neonatal citrullinemia: treatment with keto-analogues of essential amino acids. J. Pediatr., 90: 218 (1977). 
16. Williamson, D. H. Lund, P. and Krebs, H. A.: The redox state of free nicotinamide-adenine dinucleotide in the cytoplasm and mitochondria of rat liver. Biochem. J., 103: 514 (1967)

17. Walser, M., Batshaw, M. L., Sherwood, G., Robinson, B., and Brusilow, S.: Nitrogen metabolism in neonatal citrullinaemia. Clin. Sci. Mol. Med., 53: 173 (1977).

18. All studies on patients were done under protocols approved by the Johns Hopkins Joint Committee on Clinical Investigation.

19. The authors gratefully acknowledge the technical assistance of E. Gordes and E.
Bull and the cooperation of Drs. Y. Roan, A. L. Jung, W. Maddrew, and A. Glasgow. Statistical analysis was done with the help of C. Kallman.

20. Requests for reprints should be addressed to: Mark L. Batshaw, M.D., John F. Kennedy Institute, 707 N. Broadway, Baltimore, MD 21205 (USA).

21. This research was supported by United States Public Health Service grants RO1HD11134, POI-AM18020, KO7-NS00342, MOI-RR00052, and the National Foundation.

22. Received for publication November 27, 1979.

23. Accepted for publication February 21, 1980.

Copyright $(\subset) 1980$ International Pediatric Research Foundation, Inc. 